and of applying nitrogenous fertilizers to raise the protein content of crops of high-energy content.

In Britain there is the problem of making efficient rations for the livestock with feeding-stuffs of diverse and fluctuating origin and kind. The nation is dependent on the technological capacity of manufacturers abroad; for example, half the national supply of protein concentrates was imported in 1953 and 1954. In 1955 there was a large increase in supplies, mainly of imported oilseed meals. So far, continued Dr. Duckworth, little research on the nutritive value and still less on local processing methods has been published from most sources of these feeding-stuffs. Processing has generally a profound effect on the nutritive value of protein concentrates and, if inadequately controlled, yields highly variable products. Only on fish, herring, soyabean and cotton-seed meals has extensive research been done, and then almost entirely from the point of view of suiting the products to non-ruminant needs. A recent trend has been to process oil-seed meals for high solubility of protein. Such materials are contra-indicated for ruminants under preferred British feeding systems. Attention is now being given to developing rapid laboratory tests of protein quality. If success is attained, an appropriate amendment of the Fertilizer and Feeding Stuffs Act would give protection against low-value protein concentrates of domestic or imported origin, and thus lead to more efficient compounding of rations.

Many members and visitors took part in the discussion which followed.

\title{
SCIENCE HOUSE, PAKISTAN
}

$\mathrm{T}$ $\mathrm{HE}$ visitor to Pakistan cannot fail to be impressed by the rapid scientific development which is taking place there. The science departments in the older universities are expanding; new universities have been created in Sind, Karachi, Peshawar and Rajshahi; the Central and three Regional Laboratories of the Pakistan Council of Scientific and Industrial Research have been established, and important research institutions, such as the Cotton Research Institute, the Jute Research Laboratory, the Pakistan. Standards Laboratory and others, have come into being during the past three years. The new buildings, many of which have been completed, are very impressive. The sites are spacious and convenient, and the buildings, of pleasing design, have been planned with imagination and foresight. There is ample accommodation for many years to come, and expansion will not be hampered by considerations of space. These institutions have been provided by the State, and are a reflexion of the importance attached by the Government to the part which science must play in the development of the country.

The Pakistan Association for the Advancement of Science was founded in 1947, and has been very active, having started the publication of Pakistan's first scientific journals-the Pakistan Journal of Science and the Pakistan Journal of Scientific Research-and organized the annual All-Pakistan Science Conferences.

A new development of great importance has just been launched. The foundation stone of the Ismail Aiwan-i-Science (Sciénce House), Lahore, was laid on January 27, 1956, jointly by Mr. Nasser Ahmad
Shaikh, and the representatives of science associations from Australia, China, India, Pakistan, the U.S.S.R., the United Kingdom and the United States.

Science House will be the integrating centre for science in Pakistan. It will contain a large science library and a bibliographic, translation and documentation centre equipped for microfilming and duplication. There will be an auditorium to seat a thousand persons. There will be accommodation for a Human Relations Research Centre, which will be concerned chiefly with social science research. Science House will also contain office accommodation for the various scientific societies, together with seminar and committee rooms, and a press and publications section for the various scientific societies and organizations. There will be residential accommodation for visiting scientists, club rooms and a cafeteria.

The building is situated in the new modern residential centre of Lahore, adjacent to the new Regional Laboratories of the Council of Scientific and Industrial Research, and close to a number of important educational institutions and the proposed new site for the University of the Panjab.

This magnificent project was conceived by Dr. Bashir Ahmad and his colleagues, and has been made possible through the generosity of Mr. Nasser Ahmad Shaikh, a leading industrialist in Pakistan, who has provided the funds for building Science House.

The new building will be completed early in 1957, and the next annual meeting of the Pakistan Association for the Advancement of Science will be held in it.

George Aruen

\section{OBITUARIES}

\section{Dr. Walter Sydney Adams, For.Mem.R.S.}

Walter Sydney Adams, the son of a missionary, was born in Antioch in northern Syria on December 20, 1876. He was educated at Dartmouth College and the Universities of Chicago and Munich, and was appointed an assistant at the Yerkes Observatory under Hale in 1901. In 1904 he was one of the small staff which went with Hale to Mount Wilson to start the new Observatory in California. As assistant astronomer, as assistant director, as acting director during Hale's illness, and from 1923 onwards as director, he devoted his life to the Observatory until his retirement in 1946. As a research associate of the Carnegie Institution of Washington and of the California Institute of Technology, he continued working on astrophysical problems, his last paper on the shell star $\alpha$ Orionis appearing in the March issue of the Astrophysical Journal this year. $\mathrm{He}$ died on May 11, 1956.

Adams's earliest publications were on line-of-sight velocities of stars, on spectroscopic binary orbits, on stars of variable velocity and on details of spectro. 